\title{
Culturable diversity of halophilic bacteria in foreshore soils
}

\author{
Aarzoo Irshad ${ }^{1}$, Irshad Ahmad ${ }^{2}$, Seung Bum Kim ${ }^{1}$ \\ ${ }^{1}$ Department of Microbiology, School of Bioscience and Biotechnology, \\ Chungnam National University, Yuseong, Daejeon, Republic of Korea. \\ ${ }^{2}$ Biology Department, King Fahd University of Petroleum and Minerals, \\ Dhahran, Saudi Arabia.
}

Submitted: January 15, 2013; Approved: September 9, 2013.

\begin{abstract}
Halophilic bacteria are commonly found in natural environments containing significant concentration of $\mathrm{NaCl}$ such as inland salt lakes and evaporated sea-shore pools, as well as environments such as curing brines, salted food products and saline soils. Dependence on salt is an important phenotypic characteristic of halophilic bacteria, which can be used in the polyphasic characterization of newly discovered microorganisms. In this study the diversity of halophilic bacteria in foreshore soils of Daecheon, Chungnam, and Saemangeum, Jeonbuk, was investigated. Two types of media, namely NA and R2A supplemented with $3 \%, 5 \%, 9 \%, 15 \%, 20 \%$ and $30 \% \mathrm{NaCl}$ were used. More than 200 halophilic bacteria were isolated and BOX-PCR fingerprinting analysis was done for the typing of the isolates. The BLAST identification results showed that isolated strains were composed of 4 phyla, Firmicutes (60\%), Proteobacteria (31\%), Bacteriodetes (5\%) and Actinobacteria (4\%). Isolates were affiliated with 16 genera and 36 species. Bacillus was the dominant genus in the phylum Firmicutes, comprising $24 \%$ of the total isolates. Halomonas (12\%) and Shewanella $(12 \%)$ were also found as the main genera. These findings show that the foreshore soil of Daecheon Beach and Saemangeum Sea of Korea represents an untapped source of bacterial biodiversity.
\end{abstract}

Key words: culturable diversity, halophilic bacteria, foreshore soil.

\section{Introduction}

Halophiles are basically salt-loving organisms that inhabit hypersaline environments. Halophilic bacteria can be classified according to their salt requirement and growth pattern. Slight halophiles show optimum growth at 2-5\% $\mathrm{NaCl}$, moderate halophiles at $5-20 \% \mathrm{NaCl}$, and extreme halophiles show $20-30 \% \mathrm{NaCl}$ respectively. Many halophiles and halotolerant microorganisms can grow over a wide range of salt concentrations with occasionally depending on environmental and nutritional factors for the growth and tolerance (DasSarma, 2001; DasSarma and Arora, 2002; Das et al., 2006).

Moderately halophilic bacteria are a group of halophilic microorganisms able to grow optimally in media containing $5-20 \% \mathrm{NaCl}$ (Ventosa et al., 1998). Apart from their ecological importance, moderately halophilic bacteria have great potential for its use in biotechnology. Moderately halophilic bacteria form a diverse group of microorganisms adapted to the hypersaline environments. Most species of moderately halophilic bacteria keep their intracellular ionic concentrations at low levels while synthesizing or accumulating organic solutes to provide osmotic equilibrium of the cytoplasm with the surrounding medium (De Bruijn, 1992; Ghasemi et al., 2011a; 2011b; Oren, 1999). Some species of moderately halophilic bacteria are used for the degradation of polluting industrial residues or toxic chemicals and for enhanced oil-recovery processes (Birbir and Ilgaz, 1996; Ventosa and Nieto, 1995). Moreover, moderately halophilic bacteria produce extracellular salt tolerant enzymes of great interest for biotechnological processes (Birbir and Ilgaz, 1996; $\mathrm{Li}$ and $\mathrm{Yu}$, 2012; Onishi et al., 1991; Shafiei et al., 2012). Extracellular proteins, such as those secreted into the medium and proba-

Send correspondence to I. Ahmad. Department of Biotechnology, Sarhad University of Science and Information Technology, Peshawar, Khyber Pakhtunkhwa, Pakistan. E-mail: adenzai_ia@yahoo.com. 
bly those in the periplasmic space, are exposed to external saline environments and must adapt to variable salinities. They constitute a heterogeneous group of microorganisms including species belonging to various genera, such as Halomonas and Salinivibrio, which have been studied with respect to their ecology, physiology, biochemistry and genetics (Ventosa et al., 1998; Ventosa, 2006).

Extremely halophilic bacteria grow optimally at salt concentrations from above $20 \%(\mathrm{w} / \mathrm{v})$ to saturation (Ventosa, 2006). They have the capability of producing hydrolytic enzymes such as amylase and lipase. The potential importance of extremely halophiles in various industrial areas such as the leather industry and food preservation is evident (Birbir and Ilgaz, 1996; Mellado and Ventosa, 2003).

Halophilic bacteria provide a high potential for biotechnological applications for at least two reasons: 1. their activities in natural environments with regard to their participation in biogeochemical processes of $\mathrm{C}, \mathrm{N}, \mathrm{S}$, and $\mathrm{P}$, the formation and dissolution of carbonates, the immobilization of phosphate, and the production of growth factors and nutrients and 2. their nutritional requirements are simple. Most of them can grow at high salt concentrations, minimizing the risk of contamination. Moreover, several genetic tools developed for the non halophilic bacteria can be applied to the halophiles, and hence their genetic manipulation seems feasible (Rodriguez-Valera, 1993; Ventosa et al., 1998).

Current research is focused on microorganisms adapted to live in saline environment. Foreshore soil is enriched with salts and nutrients which provide a conducive environment for the growth of halophilic microorganisms. Therefore samples were collected from the foreshore soil (Daecheon Beach, Chungnam Province and Saemangeum Sea, Jeonbuk Province in South Korea) to determine the culturable bacterial diversity associated with marine environment.

\section{Materials and Methods}

The chemical reagents used in this research work were of analytical grade and purchased from Sigma, Merck, Acros and Fisher scientific chemical companies.

\section{Collection of samples}

The sampling sites are located in Chungnam and Jeonbuk Provinces in Korea. In Chungnam Province, the samples were collected from the foreshore soil of Daecheon Beach (Site A). In Jeonbuk Province samples were collected from the saline sea water (Site B) and foreshore soil of Saemangeum Sea (Site C). 25 samples each from saline sites $\mathrm{A}$ and $\mathrm{C}$ were collected at $10 \mathrm{~cm}$ depth with the help of sterilized soil corers and were transferred individually into sterile tubes (50 mL, Corning, USA). Similarly 25 samples from site B were collected $10 \mathrm{~cm}$ below the water surface with $50 \mathrm{~mL}$ sterile pipettes and transferred to $200 \mathrm{~mL}$ sterile bottles. The collected samples were put in an icebox, and then transported to the laboratory and processed immediately.

\section{Isolation of halophilic bacteria}

The procedure of heat treatment used was previously described by (Cho et al., 2006; Seong, 1992). For the isolation of halophilic bacteria, $10 \mathrm{~mL}$ of sterile $1 / 4$ strength Ringer's solution (2.25 g sodium chloride, 0.105 g potassium chloride, $0.12 \mathrm{~g}$ calcium chloride, and $0.05 \mathrm{~g}$ sodium bicarbonate in 11 distilled water) was added to 1 gram soil sample. The tenfold diluents were shaken on reciprocal shaker for $20 \mathrm{~min}$ and then incubated at $50{ }^{\circ} \mathrm{C}$ for $15 \mathrm{~min}$. Aliquots $(0.2 \mathrm{~mL})$ of each dilution were spread onto NA medium contained $(\mathrm{g} / \mathrm{L})$ : beef extract (3.0), peptone (5.0), agar (15.0) and R2A medium contained $(\mathrm{g} / \mathrm{L})$ : yeast extract $(0.5)$, proteose peptone $(0.5)$, casamino acids $(0.5)$, dextrose $(0.5)$, soluble starch $(0.5)$, sodium pyruvate $(0.3)$, dipotassium phosphate (0.3), magnesium sulphate (0.05), agar (15.0). The NA and R2A media plates were supplemented with $3 \%, 5 \%, 9 \%, 15 \%, 20 \%$ and $30 \% \mathrm{NaCl}$. Inoculated plates were incubated at $30{ }^{\circ} \mathrm{C}$ for at least one week. The colonies of halophilic bacteria were selected and subcultured using the same media.

\section{DNA extraction and purification}

DNA was extracted from the halophilic bacteria using the following protocol. The bacterial cells were taken into an Eppendorf tube containing $100 \mu \mathrm{L}$ of STES buffer (500 mM NaCl, $200 \mathrm{mM}$ Tris-Cl (pH 7.6) and $10 \mathrm{mM}$ EDTA, 1\% SDS) and glass beads. The mixture was vortexed for 5 min using a TOMY micro tube mixer (TOMY, Japan) and then $200 \mu \mathrm{L}$ of TE buffer ( $\mathrm{pH}$ 8.0) was added. DNA was purified through phenol/chloroform/isoamyl alcohol (25:24:1) extraction. RNA was removed by RNase A treatment at $37^{\circ} \mathrm{C}$ for $3 \mathrm{~h}$. The purified DNA was precipitated with 0.1 volumes of $3 \mathrm{M}$ sodium acetate and 2 volumes of cold $95 \%$ ethanol, and then centrifuged at $12,000 \mathrm{~g}$ for $20 \mathrm{~min}$ at room temperature. The supernatant was removed and the pellet was washed with $70 \%$ ethanol, dried in air and then resuspended in $50 \mu \mathrm{L}$ of TE buffer. The resuspended DNA was stored at $-20^{\circ} \mathrm{C}$ until required.

\section{Box-PCR analysis}

The 22-mer BOXAIR primer (5'-CTACGGCAAGGCGACGCTGACG-3') was used to generate BOX-PCR profiles $(10,24)$. One PCR reaction (reaction volume $25 \mu \mathrm{L}$ ) contained $2.5 \mu \mathrm{L} \mathrm{10x}$ buffer, $2 \mu \mathrm{L}$ $\mathrm{dNTP}, 3 \mu \mathrm{L}$ DMSO 100\% , $2 \mu \mathrm{L}$ primer (BOXA1R, $0.3 \mu \mathrm{g} \mu \mathrm{L}^{-1}$, Pharmacia), $0.25 \mu \mathrm{L}$ Taq polymerase and $1 \mu \mathrm{L}$ purified DNA.

The Box-PCR consisted of an initial denaturation step at $94{ }^{\circ} \mathrm{C}$ for $7 \mathrm{~min}$, which was followed by 35 cycles of $94{ }^{\circ} \mathrm{C}$ for $1 \mathrm{~min}, 60^{\circ} \mathrm{C}$ for $1 \mathrm{~min}, 65^{\circ} \mathrm{C}$ for $8 \mathrm{~min}$, and then three cycles at $65{ }^{\circ} \mathrm{C}$ for $16 \mathrm{~min}$. The PCR amplification 
products were detected by electrophoresis on $2 \%$ agarose gels in $0.5 \mathrm{x}$ Tris-borate-EDTA (TBE) buffer, which were stained with ethidium bromide (EtBr $1.25 \mathrm{mg} / \mathrm{L}$ ), visualized under UV light and the image was printed.

\section{PCR amplification and sequencing of 165 rDNA}

PCR amplification of 16S rDNA was carried out us-

ing two universal primers, $27 \mathrm{f}$ (5'-AGAGTTTGATCMTGGCTCAG-3') and 1492r (5'-GGYTACCTTGTTACGACTT-3'), which were also used for sequencing. The PCR consisted of an initial denaturation step at $95^{\circ} \mathrm{C}$ for $3 \mathrm{~min}$, which was followed by 30 cycles of $95^{\circ} \mathrm{C}$ for $1 \mathrm{~min}, 55^{\circ} \mathrm{C}$ for $40 \mathrm{~min}$ and $72^{\circ} \mathrm{C}$ for $1 \mathrm{~min}$. Sequencing was performed using the service of Solgent Co. (Korea).

\section{Phylogenetic analysis}

The 16S rDNA sequences of the isolates were compared with the sequences available by the BLAST search in the NCBI, GenBank database (http://www.ncbi.nlm.nih.gov). The sequences were proofread, edited and merged into comparable sequences using the PHYDIT program version 3.0 (available at http://plaza.snu.ac.kr/ jchun/phydit/). The sequences were aligned together with those of reference taxa retrieved from public databases. The evolutionary distances were generated based on parameter model (Jukes and Cantor, 1969) and phylogenetic trees were constructed by using the neighbor-joining method (Saitou and Nei, 1987).

\section{Results}

\section{Isolation and viable counts of halophilic bacteria}

For the specific isolation of halophilic bacteria, NA and R2A media supplemented with 3\%, 5\%, 9\%, 15\%, 20\% and $30 \% \mathrm{NaCl}$ were used. Maximum number of halophilic bacterial colonies was observed on $3 \%, 5 \%$ and $9 \% \mathrm{NaCl}$ media plates. The highest CFU counts $\left(2.3 \times 10^{8}, 1.8 \times 10^{8}\right.$, and $1.1 \times 10^{8} \mathrm{CFU} / \mathrm{g}$ ) were obtained from $3 \%, 5 \%$ and $9 \%$ $\mathrm{NaCl}$ respectively (Figure 1). On $15 \%$ and $20 \% \mathrm{NaCl}$ less growth of halophilic bacteria was obtained. There was no growth on $30 \% \mathrm{NaCl}$ media plates. Our isolates did not show any growth on media without $\mathrm{NaCl}$ (data not shown). Most halophilic bacteria were isolated from site C (112 isolates) followed by site A (66 isolates), and relatively less number of halophilic bacteria were isolated from site B (22 isolates). Among 200 isolates 108 were obtained on R2A medium while 92 were obtained on NA medium. These results showed that site C (Saemangeum Sea) of Korea represents an untapped source of halophilic bacterial diversity. Most of the isolates were moderately halophilic bacteria. Two hundred halophilic bacteria were isolated and subjected to further molecular characterization.

\section{Box-PCR analysis}

The BOX-PCR products from 200 halophilic bacterial strains were developed on agarose gel $(2 \%)$, and the patterns were analyzed by Gel Compare II software. The numbers of recognizable bands were between 4 and 12 for

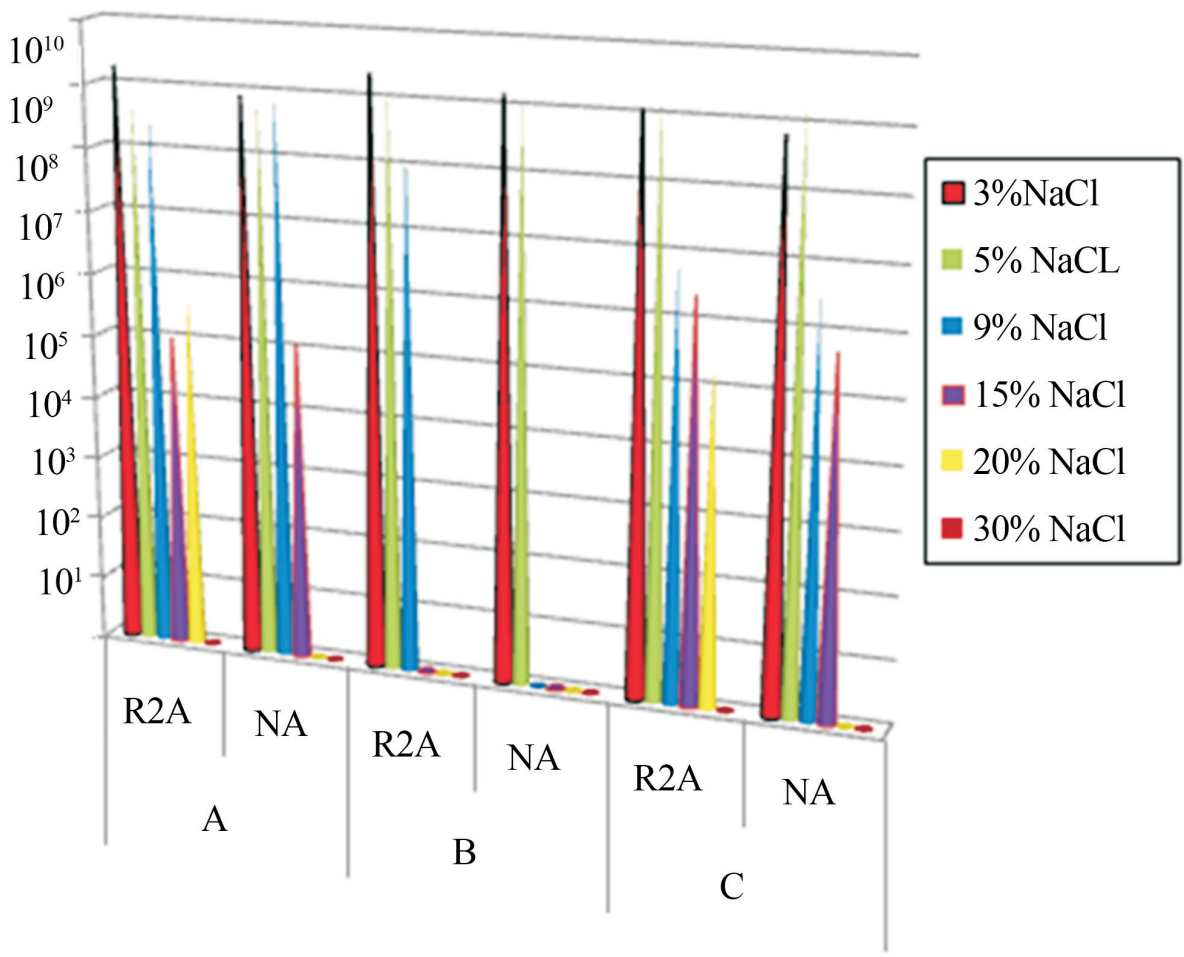

Figure 1 - Concentration of halophilic bacteria on different media. 
each strain. From the cluster analysis with the fingerprint data, 80 distinct groups could be recognized (Figure 2). On the basis of variation in banding pattern 80 strains were selected for sequencing and phylogentic analysis. The majority of the strains analyzed had different BOX patterns, confirming the high discriminative power of the BOX-PCR fingerprint technique and reporting high diversity of halophilic bacteria in marine environment.

\section{Phylogenetic analysis using 16S rDNA}

In the sequenced strains Phylogenetic analysis revealed that the isolated strains were composed of 4 phyla, Firmicutes (60.4\%), Proteobacteria (31.4\%), Bacteroidetes (4.8\%) and Actinobacteria (3.2\%) (Table 1). Among 200 isolates, $16 \mathrm{~S}$ rDNA sequences of 80 halophilic bacterial strains were sequenced, in which 47 strains showed diversity (Tables 2-3). The phylogenetic relationships between the isolated 16S rRNA gene sequences compared to those of representative species are illustrated in Figures 3 and 4. All of the isolates were affiliated with 16 genera. The isolates belonging to Firmicutes were assigned to the genera Bacillus, Halobacillus, Staphylococcus, Planococcus, Exiguobacterium and Lysinibacillus. Isolates that belong to the phylum Proteobacteria were assigned to the genera Halomonas, Shewanella, Psychrobacter, Marinobacter, Pseudomonas, Amphritea and Rhodobacter. The isolates of the phylum Bacteroidetes were assigned to the genera Cyclobacterium and Gramella. Bacterial strains of the phylum Actinobacteria were assigned to the genus Leifsonia.

Table 1 - Taxonomic composition of halophilic isolates from three sites.

\begin{tabular}{|c|c|c|c|c|}
\hline \multirow[t]{3}{*}{ Phylum } & \multirow[t]{3}{*}{ Genus } & \multicolumn{3}{|c|}{ Proportion of isolates $(\%)$} \\
\hline & & \multirow{2}{*}{$\frac{\text { Daecheon }}{\text { Soil }}$} & \multicolumn{2}{|c|}{ Saemangeum } \\
\hline & & & Soil & Seawater \\
\hline Actinobacteria & Leifsonia & 0 & 0 & 4 \\
\hline \multirow[t]{2}{*}{ Bacteroidetes } & Gramella & 2 & 0 & 0 \\
\hline & Cyclobacterium & 3 & 0 & 0 \\
\hline \multirow[t]{6}{*}{ Firmicutes } & Bacillus & 6 & 16 & 2 \\
\hline & Halobacillus & 4 & 4 & 0 \\
\hline & Lysinibacillus & 0 & 5 & 0 \\
\hline & Staphylococcus & 4 & 3 & 0 \\
\hline & Planococcus & 3 & 5 & 0 \\
\hline & Exiguobacterium & 3 & 5 & 0 \\
\hline \multirow[t]{7}{*}{ Proteobacteria } & Halomonas & 8 & 4 & 0 \\
\hline & Shewanella & 2 & 10 & 0 \\
\hline & Psychrobacter & 0 & 2 & 0 \\
\hline & Marinobacter & 2 & 0 & 0 \\
\hline & Pseudomonas & 0 & 1 & 0 \\
\hline & Rhodobacter & 0 & 1 & 0 \\
\hline & Amphritea & 1 & 0 & 0 \\
\hline
\end{tabular}

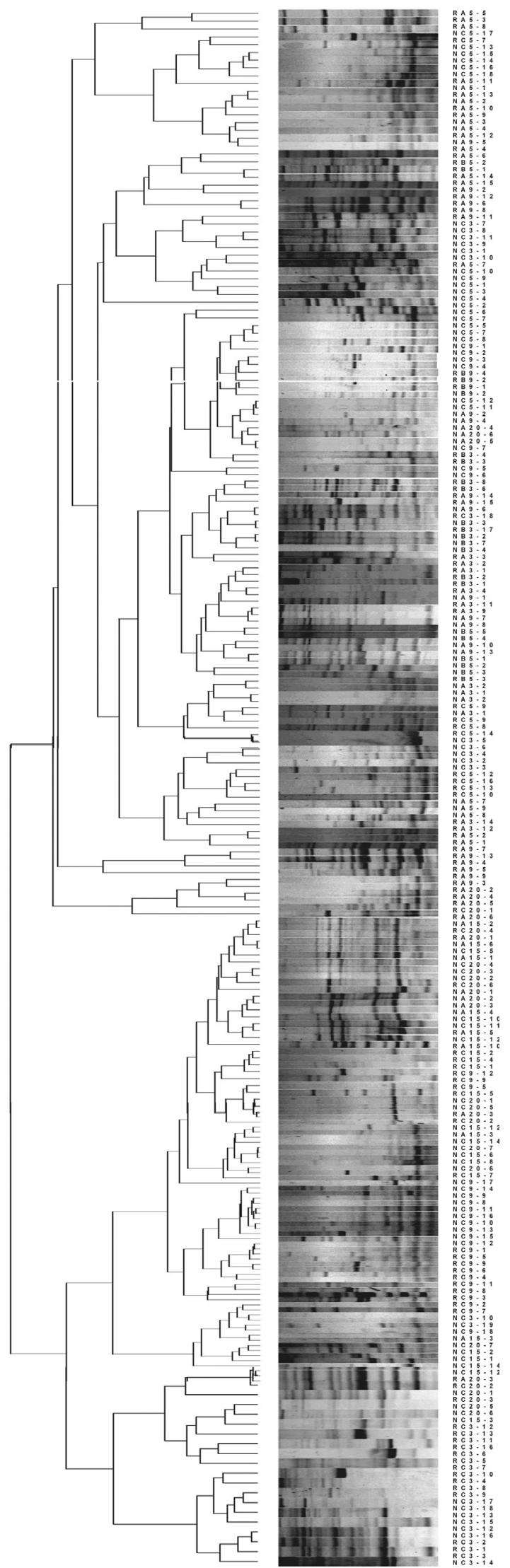

Figure 2 - Dendrogram showing variation in the banding pattern of 200 halophilic bacterial strains. 
Table 2 - Summary information of 16S rDNA sequence determination of isolates belonging to Firmicutes.

\begin{tabular}{lllc}
\hline Strain no. & Accession no. & Highest match & Similarity (\%) \\
\hline NA5-3 & DQ289988 & Bacillus cereus & $99 \%$ \\
NC3-3 & EU835729 & Bacillus aquimaris & $98 \%$ \\
NC3-12 & EU231635 & Bacillus aquimaris & $94 \%$ \\
RC15-5 & EU231632.1 & Bacillus aquimaris & $99 \%$ \\
RC3-16 & EU231635 & Bacillus aquimaris & $98 \%$ \\
RA3-14 & GQ927173 & Bacillus megaterium & $99 \%$ \\
NC3-16 & AF541965 & Bacillus baekryungensis & $98 \%$ \\
RA5-2 & DQ289988 & Bacillus cereus & $99 \%$ \\
RB5-1 & DQ289988 & Bacillus cereus & $99 \%$ \\
RC3-3 & EU333886 & Bacillus megaterium & $99 \%$ \\
NC9-2 & EU835729 & Bacillus aquimaris & $98 \%$ \\
RA5-14 & FJ227501 & Bacillus cereus & $99 \%$ \\
RC3-5 & AY505507 & Bacillus baekryungensis & $99 \%$ \\
NB5-1 & EU257697 & Bacillus licheniformis & $99 \%$ \\
RC20-2 & AY543169 & Virgibacillus halodenitrificans & $99 \%$ \\
RA9-9 & AB243865 & Halobacillus faecis & $99 \%$ \\
RC15-7 & AY505522 & Halobacillus trueperi & $99 \%$ \\
NC20-1 & AY505522 & Halobacillus trueperi & $99 \%$ \\
RC5-13 & AY505522 & Lysinibacillus sphaericus & $96 \%$ \\
RA5-13 & EU071603 & Staphylococcus capitis & $99 \%$ \\
NA15-3 & L37599 & Staphylococcus pettenkoferi & $98 \%$ \\
NC3-8 & FJ222447 & Planococcus citreus & $97 \%$ \\
RA9-3 & AF500008 & Planococcus citreus & $99 \%$ \\
RC3-10 & FJ373028 & Exiguobacterium oxidotolerans & $98 \%$ \\
NA9-7 & EF530574 & Exiguobacterium aestuarii & $98 \%$ \\
\hline
\end{tabular}

Table 3 - Summary information of 16S rDNA sequence determination of isolates belonging to Proteobacteria, Bacteroidetes and Actinobacteria.

\begin{tabular}{lllc}
\hline Strain no. & Accession no. & Highest match & Similarity (\%) \\
\hline RA5-5 & AM156910 & Amphritea atlantica & $99 \%$ \\
RA5-4 & DQ316071 & Halomonas ventosae & $96 \%$ \\
RA5-12 & AY505525 & Halomonas salina & $97 \%$ \\
NA9-2 & AM229317 & Halomonas denitrificans & $98 \%$ \\
NA20-5 & EF144149 & Halomonas saccharevitans & $98 \%$ \\
NC20-4 & AY505525 & Halomonas salina & $98 \%$ \\
NA15-4 & AM229317 & Halomonas denitrificans & $99 \%$ \\
NC5-18 & AF439803 & Pseudomonas anguilliseptica & $99 \%$ \\
NC3-10 & AJ830007 & Psychrobacter aquaticus & $97 \%$ \\
NC3-11 & EF101543 & Psychrobacter nivimaris & $96 \%$ \\
RC5-10 & D16421 & Rhodobacter veldkampii & $95 \%$ \\
RA9-12 & AY517632 & Marinobacter flavimaris & $99 \%$ \\
NA9-6 & AJ609270 & Marinobacter sedimentalis & $99 \%$ \\
RA15-15 & AY517632 & Marinobacter flavimaris & $97 \%$ \\
RA9-2 & AY517632 & Marinobacter flavimaris & $99 \%$ \\
NA3-1 & CP000753 & Shewanella baltica & $96 \%$ \\
RC3-17 & CP000753 & Shewanella baltica & $97 \%$ \\
RC3-18 & AM980878 & Shewanella vesiculosa & $98 \%$ \\
RA5-11 & AB279985 & Gramella marina & $99 \%$ \\
NA5-2 & AB279985 & Gramella marina & $97 \%$ \\
RB3-1 & DQ232614 & Leifsonia shinshuensis & $98 \%$ \\
RB3-6 & DQ232614 & Leifsonia shinshuensis & $98 \%$ \\
\hline & & & \\
\hline
\end{tabular}




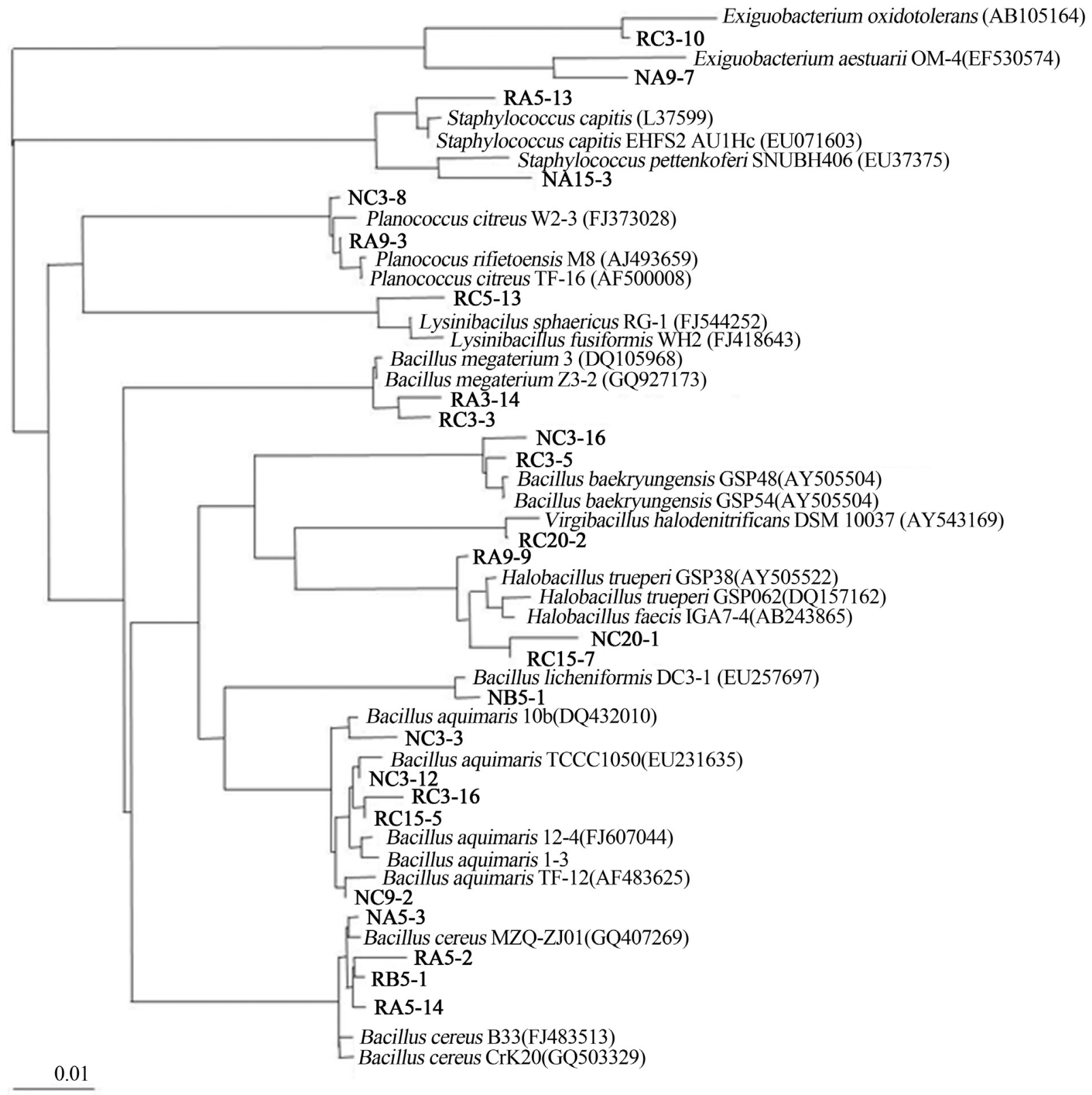

Figure 3 - Phylogenetic tree based on the 16S rDNA sequences showing the relationship among the representatives of Firmicutes. The strains isolated in this study are indicated in bold.

Bacillus was the dominant genus in the phylum Firmicutes, comprising $24 \%$ of the total isolates and exhibiting $94-99 \%$ 16S rDNA sequence similarity to published species (Table 1). The second dominant genera were Halomonas and Shewanella in the phylum Proteobacteria, representing 6\% of the isolated strains and showing 97-99\% 16S rDNA sequence similarity to known species. The third dominant genus was Psychrobacter, representing only 3\% of the strains.

\section{Discussion}

A study of halophilic bacterial diversity was carried out on foreshore soils of Daecheon Beach, Chungnam, and foreshore soils and seawater of Saemangeum Sea, Jeonbuk. The diversity of slightly, moderately, and extremely halophilic bacteria were studied using two types of media containing $3 \%, 5 \%, 9 \%, 15 \%, 20 \%$ and $30 \% \mathrm{NaCl}$. Different colonies grown on media were selected and purified for the investigation of halophilic bacterial diversity. The highest 
Rhodobacter veldkampii ATCC 35703 (D16421)

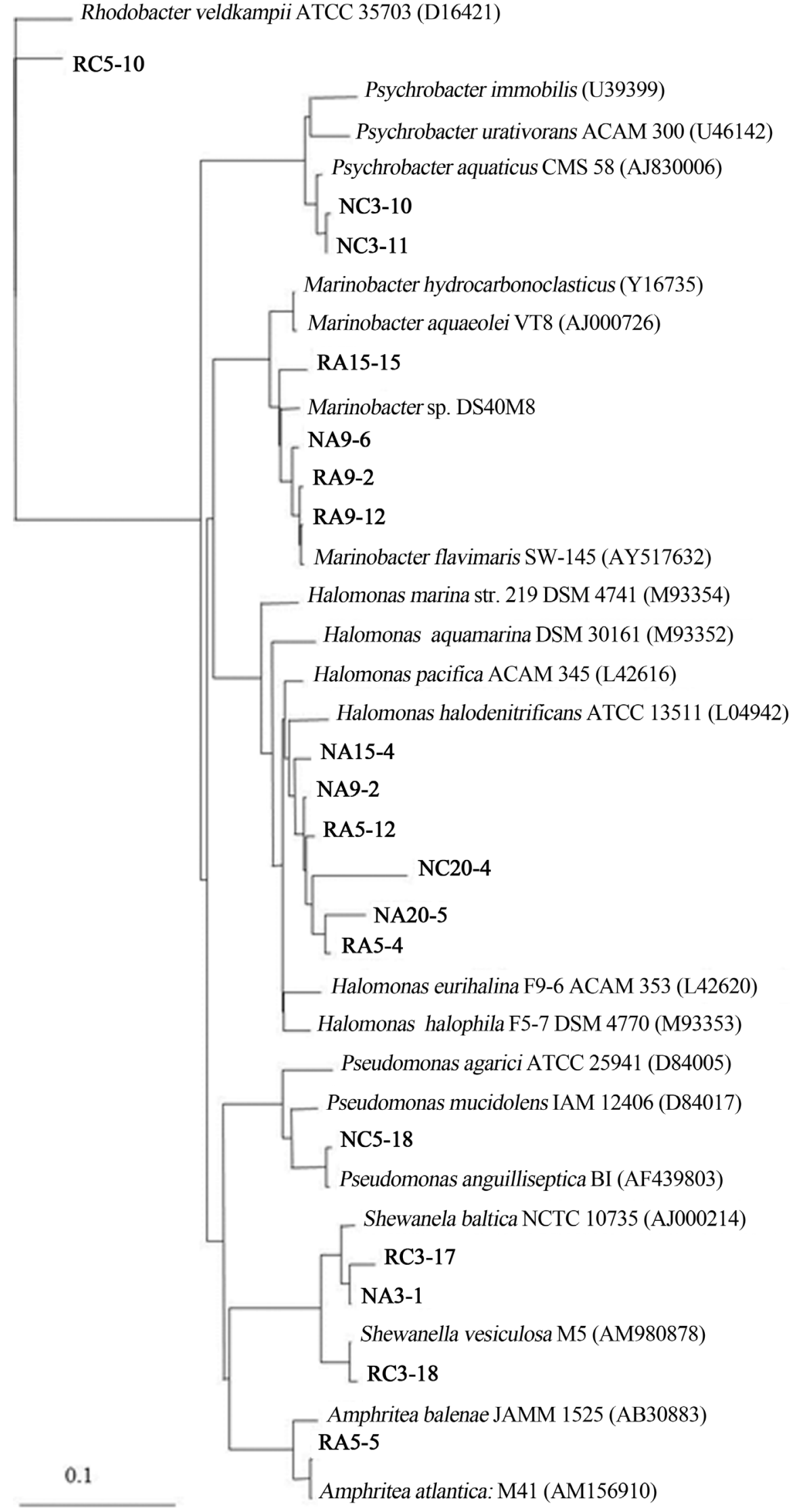

Figure 4 - Phylogenetic tree based on the 16S rDNA sequences showing the relationship among the representatives of Proteobacteria. The strains isolated in this study are indicated in bold. 
number of halophilic bacteria was found in sample $\mathrm{C}$, and the lowest number of halophilic bacteria was found in sample B. None of the isolates grew in the media with $30 \%$ $\mathrm{NaCl}$. The optimal concentration of $\mathrm{NaCl}$ was determined to be $3 \%$ and $5 \%$, and thus all of the isolates were considered to be moderate halophiles. No exceptions to this designation were found among the isolates. These results are in line with the observation that the halophilic bacterial diversity was markedly decreased as the salt concentration of the media increased. The slightly and moderately halophilic bacteria were more abundant than the extremely halophilic bacteria. These results are in good agreement with those reported by (Quesada et al., 1982; Rodriguez-Valera, 1988) in that saline soil appeared to yield largely moderately halophilic and halotolerant bacteria rather than the extremely halophilic bacteria. These phenomena are mainly due to the level of salt content in foreshore soil, which does not support the growth of extremely halophilic bacteria.

Moreover, the variation in the average counts of slightly halophilic bacteria was more correlated to the moderately halophilic bacteria than the extremely halophilic bacteria. An explanation for this phenomenon is that the slightly and moderately halophilic bacteria colonize different niches to the extremely halophilic bacteria (Oren, 1999; Oren, 2002a; 2002b). The levels of salt requirements for growth of the slightly and moderately halophilic bacteria are closer than those required for the extremely halophilic bacteria. Also the growth of extremely halophilic bacteria requires relatively high $\mathrm{NaCl}$ (at least 9\%) and the majority of them require magnesium ion $\left(\mathrm{Mg}^{2+}\right)$ for growth while the growth of slightly and moderately halophilic bacteria is not generally dependent on this cation (Grant et al., 2001).

In the present study Box-PCR technique was employed for the rapid molecular typing of 200 halophilic bacterial isolates. Box-PCR is based on the observation that outwardly facing oligonucleotide primer, complementary to interspersed repeated sequences, enables the amplification of differently sized DNA fragments, consisting of DNA sequences lying in between these elements (De Bruijn, 1992; Georghiou et al., 1994; Judd et al., 1993). The majority of the strains analyzed had different BOX patterns, confirming the high discriminative power of the BOX-PCR fingerprint technique and reporting high diversity of halophilic bacteria in marine environment.

The BLAST identification results showed that isolated strains were composed of 4 phyla, Firmicutes $(60 \%)$, Proteobacteria (31\%), Bacteriodetes $(5 \%)$ and Actinobacteria (4\%). Isolates were affiliated with 16 genera and 36 species. Bacillus was the dominant genus in the phylum Firmicutes comprising (24\%) of the total isolates. The dominance of Bacillus spp. is in line with the previous studies (Quesada et al., 1982; Rodriguez-Valera, 1988; Zahran, 1997).

The aim of this study was to evaluate halophilic bacterial diversity in foreshore soil. To our knowledge, this is the first extensive report on halophilic bacterial diversity from foreshore soil of South Korea.

\section{References}

Birbir M, Ilgaz A (1996) Isolation and identification of bacteria adversely affecting hide and leather quality. J Soc Leath Technol Chem 80:147-153.

Cho SH, Han J, Seong CN, Kim SB (2006) Phylogenetic diversity of acidophilic sporoactinobacteria isolated from various soils. J Microbiol 44:600-606.

DasSarma S, Arora P (2001) Halophiles. In: Encyclopaedia of life science. Nature Publishing Group, London, pp 1-9.

DasSarma S, Arora P (2002) Halophiles. In: Encyclopedia of Life Sciences. Nature Publishing Group, London, 8:458-466.

Das S, Lyla PS, Khan SA (2006) Marine microbial diversity and ecology: importance and future perspectives. Curr Sci 90:1325-1335.

De Bruijn FJ (1992) Use of repetitive (repetitive extragenic palindromic and enterobacterial repetitive intergenic consensus) sequences and the polymerase chain reaction to fingerprint the genomes of Rhizobium meliloti isolates and other soil bacteria. Appl Environ Mocrobiol 58:2180-2187.

Delgado-García M, Valdivia-Urdiales B, Aguilar-González CN, Contreras-Esquivel JC, Rodríguez-Herrera R (2012) Halophilic hydrolases as a new tool for the biotechnological industries. J Sci Food Agric 92:2575-2580.

Georghiou P, Doggett A, Kielhofner M, Stout J et al. (1994). J Clin Microbiol 19:2989-2994.

Ghasemi Y, Rasoul-Amini S, Ebrahiminezhad A, Kazemi A, Shahbazia M, Talebniaa N (2011a) Screening and Isolation of Extracellular Protease Producing Bacteria from the Maharloo Salt Lake. Iran J Pharm Sci 7:175-180.

Ghasemi Y, Rasoul-Amini S, Kazemi A, Zarrini G, Morowvat MT, Kargar M (2011b) Isolation and Characterization of Some Moderately Halophilic Bacteria with Lipase Activity. Mikrobiologiia 80:477-481.

Grant WD, Kamekura M, McGenity TJ, Ventosa A (2001) Class III. Halobacteria class nov. In: Boone, D.R., Castenholz, R.W. (eds). Bergey's Manual of Systematic Bacteriology, Springer, New York, pp 294

Judd AK, Schneider M, Sadowsky MJ, de Bruijn FJ (1993) Use of repetetive sequences and the polemerase chain reaction technique to classify genetically related Bradyrhizoium japonicum serocluster 123 strains. Appl Environ Microbiol 59:1702-1708.

Jukes TH, Cantor CR (1969) Evolution of protein molecules. In: Munro, H.N. (ed). Mammalian protein metabolism. Academic Press, New York, pp 21-132.

Li X, Yu HY (2012) Characterization of an organic solventtolerant $\alpha$-amylase from a halophilic isolate, Thalassobacillus sp. LY18. Folia Microbiol 57:447-453.

Martin B, Humbert O, Camara M, Guenzi E, Walker J, Mitchell T, Andrew P, Prudhomme M, Hakenbeck, R (1992) A highly conserved repeated DNA element located in the chromosome of Steptococcus pneumonia. Nucleic Acids Res 20:3479-3483.

Mellado ME, Ventosa A (2003) Biotechnological potential of moderately and extremely halophilic microorganisms. In: Barredo, J.L. (ed). Microorganisms for health care, food and enzyme production, Research Signpost, Kerala, pp 233-256. 
Onishi H, Yokoi H, Kamekura M (1991) An application of a bioreactor with flocculated cells of halophilic Micrococcus varians sub sp. Halophilus which preferentially adsorbed halophilic nuclease $\mathrm{H}$ to 5- nucleotide production. In: Rodriguez-valera, F. (ed). General and Applied Aspects of Halophilic Microorganisms. Plenum Press, New York, pp 341349 .

Oren A (1999) Bioenergetics aspects of halophilism. Microbiol Mol Biol Rev 63:334-348.

Oren A (2002a) Halophilic microorganisms and their environments: Kluwer Academic Publishers, Dordrecht, Netherlands, pp 575.

Oren A (2002b) Diversity of halophilic microorganisms: environments, phylogeny, physiology, and applications. J Ind Microbiol Biotechnol 28:56-63.

Quesada E, Ventosa A, Rodriguez-Valera F, Ramos-Cormenzana A (1982) Types and properties of some bacteria isolated from hypersaline soils. J Appl Microbiol 53:155-161.

Rodriguez-Valera F (1988) Characteristics and microbial ecology of hypersaline environments. In: Rodriguez-Valera, F. (ed). Halophilic Bacteria, CRC Press, Boca Raton, pp 3-30.

Rodriguez-Valera F (1993) Introduction to saline environments. In: Vreeland, R.H., Hochstein, L.I. (eds). The Biology of Halophilic Bacteria, CRC Press, Boca Raton, pp 1-12.

Saitou N, Nei M (1987) The neighbor joining method: a new method for constructing phylogenetic trees. Mol Biol Evol 4406-425.
Seong CN (1992) Numerical taxonomy of acidophilic and neutron tolerant actionmycetes isolated from acid soil in Korea. Ph.D. thesis, Seoul National University, Seoul, Republic of Korea.

Shafiei M, Ziaee AA, Amoozegar MA (2012) Purification and characterization of a halophilic-amylase with increased activity in the presence of organic solvents from the moderately halophilic Nesterenkonia sp. strain F. Extremophiles 16:627-635.

Ventos A, Nieto JJ (1995) Biotechnological applications and potentialities of halophilic microorganisms. World J Microbiol Biotechnol 11:85-94.

Ventosa A, Nieto JJ, Oren A (1998) Biology of moderately halophilic aerobic bacteria. Microbiol Mol Biol Rev 62:504-544.

Ventosa A (2006) Unusual microorganisms from unusual habitats: hypersaline environments. In: Logan, N.A., LappinScott, H.M., Oyston, P.C.F. (eds). Prokaryotic diversitymechanism and significance. Cambridge University Press, Cambridge, pp 223-253.

Versalovic J, Koeuth T, Lupski JR (1991) Distribution of repetitive DNA sequences in eubacteria and application to fingerprinting of bacterial genomes. Nucleic Acids Res 19:68236831.

Zahran HH (1997) Diversity, adaptation and activity of the bacterial flora in saline environments. Biol Fertil Soil 25:211223.

All the content of the journal, except where otherwise noted, is licensed under a Creative Commons License CC BY-NC. 